\title{
Induction of microsomal drug metabolism in man and in the rat by exposure to petroleum
}

\author{
A W HARMAN, D B FREWIN, AND B G PRIESTLY \\ From the Department of Clinical and Experimental Pharmacology, University of Adelaide, Adelaide, \\ South Australia 5000
}

ABSTRACT To determine the effect of petroleum exposure on the activity of hepatic mixed function oxidase enzymes, salivary elimination kinetics of antipyrine were determined in 19 petrol station attendants and compared with 19 controls. Antipyrine half life in petrol station attendants was shorter than in controls. Microsomal preparations $(10000 \times \mathrm{g}$ supernatants) were prepared from six male Porton rats exposed to petrol vapour $(5 \mathrm{ppm}$ at an air flow rate of $41 / \mathrm{min}$ for eight hours a day for three weeks) and six control rats maintained under the same conditions without exposure to petrol vapour. The rates of oxidative metabolism of antipyrine, aminopyrine, ethylmorphine, aniline, and benzo(a)pyrene were all increased by more than $45 \%$ in the petrol-exposed rats. The results indicate that petrol vapour is a moderately potent inducer of mixed function oxidase activity in rats, and that occupational exposure to petroleum may result in enhanced microsomal drug metabolism.

The activity of the hepatic mixed function oxygenases may be induced by many heterogeneous lipophilic compounds. Such chemicals are proliferating in the environment, and it is of some interest to know which of these agents are capable of causing microsomal enzyme induction in man.

Several environmental chemicals are known to be able to cause microsomal enzyme induction in animals. ${ }^{12}$ Among these are pesticides, such as DDT, chlordane and dieldrin, and polycyclic hydrocarbons, such as 3-methylcholanthrene and 3,4 benzo(a)pyrene. Evidence for enzyme-inducing effects of environmental chemicals in man is more limited. Changes in antipyrine elimination kinetics consistent with induced metabolism, however, have been detected in man after occupational exposure to chlorinated hydrocarbon insecticides, ${ }^{3}$ polychlorinated biphenyls, ${ }^{4}$ and inhalational anaesthetics. ${ }^{5}$

Petroleum is a complex mixture of a wide variety of lipophilic hydrocarbons, some of which may have the potential to induce mixed function oxidase activity. If this were the case enzyme induction might be detectable in workers occupationally ex-

Requests for reprints to: Dr D B Frewin, Department of Clinical and Experimental Pharmacology, University of Adelaide, Adelaide, South Australia 5000

Received 2 January 1980

Accepted 21 March 1980 posed to petroleum. A convenient method of assessing such induction entails the use of antipyrine as a metabolic probe combined with salivary sampling as a non-invasive procedure for sample collection. ${ }^{6}$

In the present study the kinetics of antipyrine elimination were determined in petrol station attendants, and an attempt was made to correlate this with the degree of exposure to petrol, using urinary phenol output and blood and urinary lead concentrations as indices of exposure. In addition the inductive effect of petrol on microsomal drug metabolising enzyme activity in vitro was assessed in rats after three weeks' intermittent exposure to petrol vapour.

\section{Methods}

HUMAN STUDY

\section{Subjects}

Nineteen male employees at six metropolitan petrolvending stations participated in the study. All had worked as petrol pump attendants or garage mechanics, or both, for more than one year. They were aged 16-50 (mean $\pm \mathrm{SD}, 28 \pm 10$ ), and they were not taking any medicine at the time of the study. On the morning of the third day of a five-anda-half-day working week, each subject ingested 
antipyrine $(10 \mathrm{mg} / \mathrm{kg})$ dissolved in $100 \mathrm{ml}$ of water. Mixed saliva samples were collected before and 3, 6, $9,12,24$, and 36 hours after antipyrine administration. Antipyrine concentration in saliva was assayed by a gas-liquid chromatographic technique as previously described. ${ }^{7}$ Ambient temperature at the time of the experiment was $13-19^{\circ} \mathrm{C}$. The control group consisted of 19 unmedicated men, mostly university staff and students, aged 21-69 (mean \pm SD, $29 \pm$ 12), whose exposure to petroleum products was limited to personal use of a motor vehicle.

Thirteen of the petrol station attendants and ten of the controls also participated in a study designed to assess exposure to petroleum products. On the morning before the antipyrine study, a $20-\mathrm{ml}$ venous blood sample was collected into lithium heparin $(125 \mathrm{IU} / 10 \mathrm{ml})$. On the following morning, they began a 24-hr urine collection into plastic bottles containing $50 \mathrm{ml}$ of $2 \mathrm{M}$ nitric acid as a preservative. The blood and urine samples were analysed as follows.

\section{Urine}

Phenol-Total urinary phenol output $(\mathrm{mg} / 24 \mathrm{hr})$ was determined by the distillation method of Schmidt. ${ }^{8}$

Lead-The 24-hr urinary lead output was measured by direct solvent extraction and atomic absorption spectroscopy (Standards Association of Australia, 1970).

\section{Blood}

Aminolaevulinic acid dehydratase (ALAD) activityALAD concentrations were assayed in whole blood by the colorimetric method described by Chakrabarti et $a l^{9}$ except that incubation was performed in evacuated Thunberg tubes for $30 \mathrm{~min}$.

Blood lead-One millilitre of whole EDTA blood was mixed with $4 \mathrm{ml}$ of $0.25 \%$ Triton X-100 and atomic absorption analysis performed as described by Fernandez. ${ }^{10}$

Blood biochemistry-Biochemical analysis was performed using standard Technicon autoanalyser techniques. Items measured included sodium, potassium, chloride, bicarbonate, osmolarity, glucose, urea, creatinine, urate, phosphate, calcium, albumin, globulins, cholesterol, conjugated and total bilirubin, as well as alkaline phosphatase, lactic dehydrogenase, aspartate transaminase, and creatinine kinase activities.

\section{ANIMAL STUDY}

\section{Animals}

Male Porton rats, weighing 100-150 g, were obtained from this university's animal breeding house. They were kept in a 12-hr light/dark cycle and allowed food and water ad libitum.

\section{Petrol exposure}

Perspex exposure chambers of about 40-1 capacity were supplied with an airflow of $4 \mathrm{l} / \mathrm{min}$ from a respiratory pump (C F Palmer, London). The airflow from the pump was split, with half flowing to the chamber housing six control rats and the other passing to a similar chamber via a petrol vaporising chamber that consisted of a water heated, vertical $22 \times 4 \mathrm{~cm}$ Pyrex tube. The middle $16 \mathrm{~cm}$ had a glass spiral tube through which water at $40^{\circ} \mathrm{C}$ was pumped. Petrol (commercial grade, $50 \%$ super : $50 \%$ standard) was pumped on to the top of the spiral at a rate of $20 \mathrm{mg} / \mathrm{min}$ and allowed to evaporate. Thus the six rats in this chamber were exposed to petrol vapour at a calculated concentration of $5 \mathrm{mg} / \mathrm{l}$. Both groups of rats were placed in the exposure chambers for eight hours a day for three weeks.

\section{In-vitro microsomal enzyme activities}

Rats were killed by stunning and decapitation. Blood samples $(2 \mathrm{ml})$ were collected into heparinised tubes. The livers were perfused in situ with ice-cold saline via the portal vein and placed in $20 \mathrm{ml}$ of ice-cold $0.25 \mathrm{M}$ sucrose/0.05M Tris buffer ( $\mathrm{pH} \mathrm{7.4)}$ ). All subsequent operations were carried out at $0-4^{\circ} \mathrm{C}$. The livers were weighed and homogenised for $1 \mathrm{~min}$ using an Ultra Turrax blender. The homogenate was centrifuged for $20 \mathrm{~min}$ at $10000 \times \mathrm{g}$, and the resulting supernatant decanted and the volume adjusted to $400 \mathrm{mg}$ liver $/ \mathrm{ml}$ with the sucrose/Tris buffer. The incubation mixture (total volume $3 \mathrm{ml}$ ) consisted of $0.5 \mathrm{ml}$ of the $10.000 \times \mathrm{g}$ supernatant (pre-incubated for $2 \mathrm{~min}$ ) and $5 \mathrm{mmol} / \mathrm{l} \mathrm{MgCl}_{2}, 0.33 \mathrm{mmol} / \mathrm{l}$ $\mathrm{NADP}^{+}, \quad 3.3 \mathrm{mmol} / \mathrm{l}$ glucose-6-phosphate, and substrate in $0.05 \mathrm{M}$ Tris buffer $\mathrm{pH} \mathrm{7.4}$. The incubations were carried out in glass vials in a metabolic shaker bath at $37^{\circ} \mathrm{C}$ under air at 80 oscillations/min with a glass marble to facilitate mixing. Substrate concentrations were $5 \mathrm{mmol} / \mathrm{l}$ for aminopyrine, ethylmorphine, aniline, and antipyrine and $80 \mu \mathrm{mol} / \mathrm{l}$ for benzo(a)pyrene (added as $15 \mu \mathrm{l}$ of a $4 \mathrm{mg} / \mathrm{ml}$ solution in acetone).

Aminopyrine and ethylmorphine $\mathrm{N}$-demethylase activities and aniline p-hydroxylase activity were determined as described by Schenkman et al, ${ }^{11}$ except that semicarbazide $(5 \mathrm{mmol} / \mathrm{l})$ was added to trap formaldehyde formed during demethylation. Benzo(a)pyrene hydroxylase activity was determined using the method of Nebert and Gelboin ${ }^{12}$ with the following modification. The incubation was stopped by the addition of $3 \mathrm{ml}$ ice-cold acetone, and $3 \mathrm{ml}$ of this mixture was extracted with $10 \mathrm{ml} \mathrm{n}$-hexane in a 20-ml glass extraction tube for $10 \mathrm{~min}$ and then 
centrifuged for $5 \mathrm{~min}$ at $3000 \mathrm{rpm}$. Three millilitres of the organic phase was back extracted into $3 \mathrm{ml} 1 \mathrm{M}$ $\mathrm{NaOH}$, and the fluorescence of the aqueous phase read at $522 \mathrm{~nm}$ with the excitation at $396 \mathrm{~nm}$ in a spectrofluorimeter (Farrand Optical, New York). In the blank, substrate was added after incubation. Antipyrine metabolism was determined as the amount of water soluble metabolites produced during incubation. The antipyrine used as substrate was spiked with $\mathrm{N}$-methyl-14 $\mathrm{C}$-antipyrine $(2.2 \times$ $\left.10^{5} \mathrm{dpm} / \mathrm{vial}\right)$. The reaction was stopped with $0.6 \mathrm{ml}$ $5 \mathrm{M} \mathrm{NaOH}$ and $3 \mathrm{ml}$ of this mixture was extracted with $10 \mathrm{ml}$ chloroform for $30 \mathrm{~min}$. Only unchanged antipyrine was extracted into the organic phase, ${ }^{13}$ leaving the metabolites in the aqueous phase. After centrifugation for $30 \mathrm{~min}$ at $3000 \mathrm{rpm}, 2 \mathrm{ml}$ of the aqueous medium was transferred to a plastic counting vial containing $10 \mathrm{ml}$ of scintillant $(0.17 \mathrm{~g} 1,4$-bis (2\{4-methyl-5-phenyloxazolyl\}) benzene, $5.3 \mathrm{~g}$ 2,5-diphenyloxazole, $333 \mathrm{ml}$ Triton X-100, $666 \mathrm{ml}$ toluene) and the activity determined in a liquid scintillation counter (Packard, Model 3310). In the blank, substrate was added after incubation. The amount of antipyrine metabolised, allowing for volume corrections, was determined as follows: amount metabolised $=$

$\frac{\mathrm{dpm} \text { in aqueous phase }-\mathrm{dpm} \text { in blank }}{\text { total dpm added }} \times$ initial

amount in the incubation vial.

Incubation times were $\mathbf{1 0}$ min for ethylmorphine and benzo(a)pyrene, $15 \mathrm{~min}$ for aminopyrine and aniline, and $30 \mathrm{~min}$ for antipyrine. Aniline aminotransferase (ALAT) activity and bilirubin content of rat plasma were assayed by standard Technicon autoanalyser techniques.

ANALYSIS OF DATA

Comparisons of grouped data were made using the Mann Whitney U-test. The Spearman rank correlation was used to test correlation, and the classification measurements were made using chi-squared analysis. Non-parametric confidence limits were determined as described by Colquhoun. ${ }^{14}$

\section{Results}

\section{HUMAN STUDY}

\section{Antipyrine metabolism}

Antipyrine, $10 \mathrm{mg} / \mathrm{kg}$, was given as a single oral dose to each subject and the elimination rate of antipyrine determined. As illustrated in fig 1, the half lives in petrol station attendants ranged from 4.2 to $17.9 \mathrm{hr}$ (median $9.7 \mathrm{hr}$ ), and these values were shorter than in the male control subjects whose values ranged

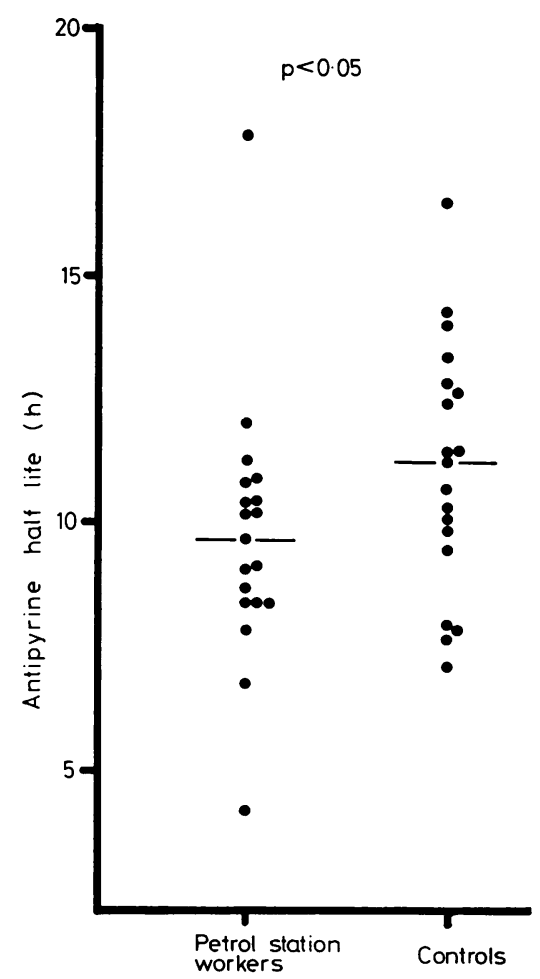

Fig 1 Antipyrine half-lives in petrol station workers and control subjects. Median value of each group is shown by a bar.

from $7 \cdot 1$ to $16.5 \mathrm{hr}$ (median $11.3 \mathrm{hr})(\mathrm{p}<0.05$, onetail).

\section{Urinary phenol}

The 24-hr urinary excretion of phenol in the 13 petrol station attendants who participated in the blood and urine collections ranged from 4.8 to $34.1 \mathrm{mg}$ (median $12.2 \mathrm{mg}$, with $98 \%$ confidence limits of 6.6 and $21.0 \mathrm{mg}$ ). These values (fig 2) were not different from those found in 10 control subjects, whose values ranged from 5.7 to $15.6 \mathrm{mg}$ (median $8.8 \mathrm{mg}$, with $98 \%$ confidence limits of 5.9 and $14.0 \mathrm{mg})(\mathrm{p}>0.05$, one-tail). The values obtained in the control subjects are similar to those found in urine from normal subjects by Schmidt. ${ }^{8}$ There was no rank correlation between antipyrine half life and phenol excretion $\left(r_{s}=0.29, p>0.05\right)$.

\section{Lead content}

Values for blood and urinary lead and blood ALAD activity in the 13 workers are shown in table 1 . The urinary lead output of the petrol station attendants ranged from 0.04 to $0.20 \mu \mathrm{mol} / 24 \mathrm{hr}$ (median 0.07 , 


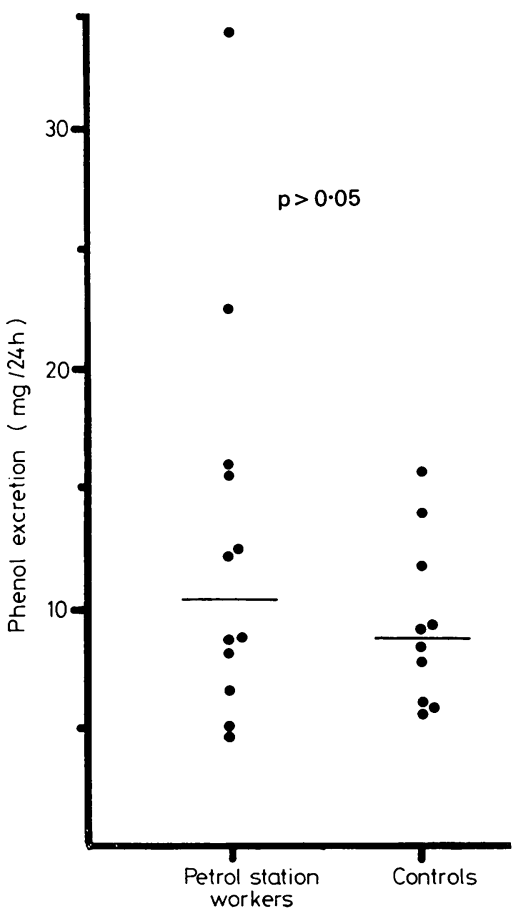

Fig 2 Amount of phenol excreted in 24-hour urine samples from 13 petrol station workers and ten controls. Median value of each group is shown by a bar.

with $98 \%$ confidence limits of 0.06 and 0.17 ) and the blood lead concentrations ranged from 0.79 to $1.56 \mu \mathrm{mol} / \mathrm{l}$ (median 0.95 , with $98 \%$ confidence

Table 1 Values for blood and urinary lead concentrations and plasma ALAD activity in 13 petrol station attendants

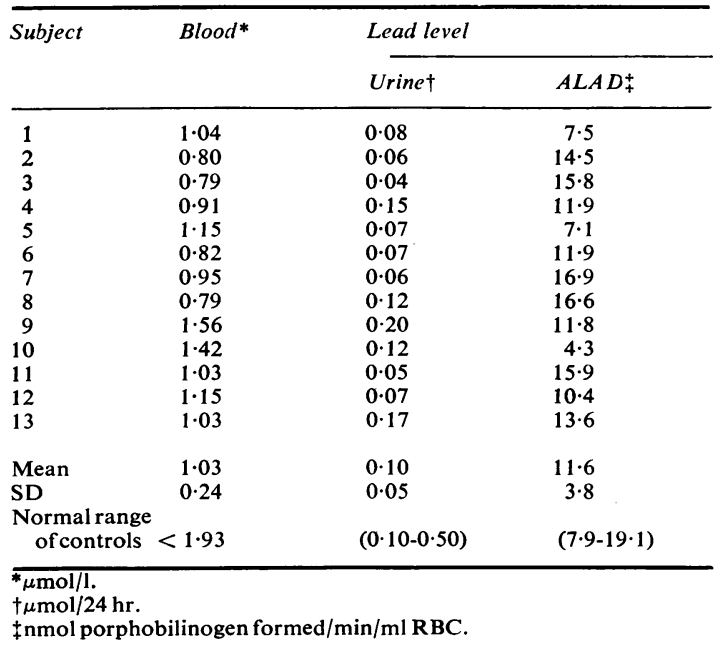

limits of 0.80 and 1.15$)$. These values are all well within the range (urine $0 \cdot 10-0.50 \mu \mathrm{mol} / 24 \mathrm{hr}$ and blood $1.7 \mu \mathrm{mol} / \mathrm{l}$ limit) quoted for normal nonexposed subjects. ${ }^{15}$ The levels of ALAD activity in the petrol station workers were consistent with the finding of normal values for blood and urinary lead ranging from 4.25 to $16.9 \mathrm{nmol}$ porphobilinogen formed $/ \mathrm{min} / \mathrm{ml} \mathrm{RBC}$, with a median of 11.8 and $98 \%$ confidence limits of 7.5 and $15 \cdot 8$. These values are comparable to the mean value of $13.5 \mathrm{nmol}$ porphobilinogen formed/min/ml RBC in 37 subjects with no known exposure to lead. ${ }^{16}$ There were no significant rank correlations between antipyrine half life and either urinary lead $\left(r_{s}=0.14, p>0.05\right)$, blood lead $\left(r_{s}=0.40, p>0.05\right)$, or ALAD $\left(r_{s}=0.19, p>0.05\right)$. A significant correlation, however, was found between blood lead concentrations and ALAD activity $\left(r_{s}=0.48, p<0.05\right)$, a result consistent with previous findings. ${ }^{9} 1617$

These results indicate that the petrol station workers did not accumulate lead to a greater extent than that expected in a normal population group.

\section{Blood biochemistry}

No abnormalities were disclosed by the biochemical tests of blood chemistry in the 13 petrol station attendants.

\section{Social history}

Consideration was given to the possibility that factors such as age, duration of employment, smoking habits, alcohol, and caffeine intake may have had some influence on antipyrine metabolism in the 19 petrol station attendants (table 2). No association was found between antipyrine half life and any of these factors.

\section{ANIMAL STUDY}

As shown in table 3, the activity of mixed function oxidases measured in the microsome-enriched $10000 \times \mathrm{g}$ supernatant preparations was increased in the petrol-exposed rats. The percentage increase ranged from $45 \%$ for benzo(a)pyrene hydroxylation to $79 \%$ for ethylmorphine $\mathrm{N}$-demethylation. All these increases were highly significant $(p<0.001$, two-tail). The liver/body weight ratio was also increased in the petrol-exposed rats $(p<0.01$, twotail), although body weights in the two groups were not different ( $p>0 \cdot 1$, two-tail), nor was the increase in body weight over the 21-day exposure $(89 \%$ in control v $75 \%$ in petrol exposure).

There was no difference in plasma alkaline phosphatase and bilirubin concentrations between control and exposed rats ( $p>0 \cdot 1$, two-tail), suggesting that exposure to petrol did not cause overt liver damage. The values for bilirubin were $0.45 \pm$ 
Table 2 Antipyrine half-lives (hours), age and work duration (years) and measures of social drug intake in 19 petrol station attendants

\begin{tabular}{|c|c|c|c|c|c|c|}
\hline Subject & Half-life & Age & Work duration & Alcohol* intake & Caffeine $†$ intake & Smoking $\ddagger$ \\
\hline 1 & $4 \cdot 2$ & 20 & 4 & 0 & 1 & 0 \\
\hline 2 & 6.8 & 16 & 1 & 1 & 2 & 1 \\
\hline 3 & $7 \cdot 8$ & 28 & 11 & 1 & 1 & 1 \\
\hline 4 & $8 \cdot 4$ & 33 & 18 & 2 & 2 & 0 \\
\hline 5 & $8 \cdot 4$ & 47 & 33 & 0 & 2 & 1 \\
\hline 6 & $8 \cdot 4$ & 22 & 7 & 1 & $\overline{1}$ & 0 \\
\hline 7 & $8 \cdot 7$ & 19 & 3 & 2 & 1 & 1 \\
\hline 8 & $9 \cdot 1$ & 23 & 7 & 1 & 1 & 0 \\
\hline 9 & $9 \cdot 1$ & 42 & 20 & 1 & 2 & 1 \\
\hline 10 & $9 \cdot 7$ & 19 & 3 & 1 & 1 & 0 \\
\hline 11 & $10 \cdot 2$ & 17. & 2 & 0 & 0 & 0 \\
\hline 12 & $10 \cdot 2$ & 42 & 25 & 0 & 2 & 0 \\
\hline 13 & $10 \cdot 4$ & 27 & 10 & 1 & 1 & 0 \\
\hline 14 & $10 \cdot 5$ & 50 & 10 & 2 & 2 & 1 \\
\hline 15 & 10.8 & 30 & 12 & 2 & 1 & 2 \\
\hline 16 & 10.9 & 20 & 2 & 0 & 1 & 0 \\
\hline 17 & $11 \cdot 3$ & 21 & 4 & 1 & 1 & 1 \\
\hline 18 & $12 \cdot 1$ & 27 & 10 & 0 & 1 & 0 \\
\hline 19 & $17 \cdot 9$ & 30 & 15 & 1 & 2 & 0 \\
\hline \multicolumn{2}{|c|}{ Correlation } & 0.1 & 0.06 & & & \\
\hline \multirow{3}{*}{\multicolumn{2}{|c|}{$\begin{array}{l}\text { coefficient } \\
\text { Chi-square }\end{array}$}} & $p>0.1$ & $\mathrm{p}>0.1$ & & & \\
\hline & & & & 0.5 & 0.36 & 0.44 \\
\hline & & & & $\mathrm{p}>0.5$ & $p>0.5$ & $\mathrm{p}>0.5$ \\
\hline
\end{tabular}

* $0=$ no alcohol $; 1=\leqslant 1$ bottle beer/day or equivalent $2=>1$ bottle beer/day.

$+0=$ no coffee or tea $; 1=\leqslant 5$ cups coffee or tea/day $; 2=>5$ cups coffee or tea/day.

$\ddagger 0=$ non-smoker $; 1=\leqslant 20$ cigarettes/day $; 2=>20$ cigarettes/day.

Table 3 Hepatic microsomal enzyme activities (mean \pm $S D ; n=6)$ and liver/body weight ratios from control and rats exposed to petrol

\begin{tabular}{lccl}
\hline & Control & Petrol exposed $\|$ & $\%$ Increase \\
\hline $\begin{array}{l}\text { Aminopyrine } \\
\begin{array}{l}\text { N-demethylase* } \\
\text { Ethylmorphine }\end{array}\end{array}$ & $74 \pm 7$ & $122 \pm 11$ & 65 \\
$\begin{array}{l}\text { N-demethylase* } \\
\text { Antipyrine }\end{array}$ & $75 \pm 10$ & $134 \pm 21$ & 79 \\
$\begin{array}{l}\text { metabolism } \\
\text { Aniline }\end{array}$ & $35 \pm 2$ & $54 \pm 5$ & 54 \\
$\begin{array}{l}\text { hydroxylase }+ \\
\text { Benzo(a)pyrene } \\
\text { hydroxylase } \S\end{array}$ & $21 \pm 1$ & $33 \pm 3$ & 57 \\
$\begin{array}{l}\text { Liver/body } \\
\text { weight ratio }\end{array}$ & $0.059 \pm 0.001$ & $0.067 \pm 0.002$ & 14 \\
\hline
\end{tabular}

${ }^{*} \mathrm{nmol} \mathrm{HCHO} / \mathrm{min} / \mathrm{g}$

tnmol ${ }^{14} \mathrm{C} / \mathrm{min} / \mathrm{g}$.

$+\mathrm{nmol}$ PAP $/ \mathrm{min} / \mathrm{g}$.

$\$$ Relative fluorescence units.

All values significantly greater than control $(p<0.01)$.

$0.33 \mathrm{mg} / 100 \mathrm{ml}$ in controls and $0.28 \pm 0.18$ in exposed rats, and the levels for ALAT activity were $45 \cdot 7 \pm 11 \cdot 3 \mathrm{IU} / \mathrm{l}$ in controls and $46 \cdot 2 \pm 12 \cdot 0 \mathrm{IU} / 1 \mathrm{in}$ exposed rats.

\section{Discussion}

In this study antipyrine metabolism in a group of petrol station attendants was enhanced when compared with a group of subjects not occupationally exposed to petroleum. The implication of this finding is that one or more chemicals in the petrol station environment is a microsomal enzyme inducer. Since petrol consists of a heterogeneous mixture of hydrocarbon molecules, with the number of carbon atoms ranging from four to 12 a molecule, it is an obvious candidate, although it is useless to speculate which compounds or types of compounds are the potential inducing agents in this mixture.

Previous studies in animals have shown the potential of petroleum to induce microsomal enzymes. Payne and Penrose ${ }^{18}$ found increased aryl hydrocarbon (benzo(a)pyrene) hydroxylase activity in microsomal preparations of fish exposed to a $1 \mathrm{ppm}$ emulsion of crude oil in water. Halogenated benzenes (compounds found in petrol) increased cytochrome $\mathbf{P}_{450}$ content in the liver of rats given daily doses of $20 \mathrm{mg} / \mathrm{kg}$ po. ${ }^{19}$ No previous studies in man have shown petrol-induced microsomal enzyme activity. Although increased serum activity of glucose-6phosphate dehydrogenase, glucose-6-phosphate isomerase, and ornithinecarbamoyl transferase have been reported in oil-tanker fleet workers, 20 it is questionable whether these changes reflect the activity of membrane-bound enzymes in the liver.

Rats exposed to petrol vapour during simulated working conditions over a period of 21 days were used to confirm that petrol might be the agent responsible for enhancement of antipyrine elimination in man. Induced in-vitro metabolism was found for all five of the cytochrome $\mathbf{P}_{450}$ substrates tested. Hence the effect seems to be that of generalised induction of the microsomal mixed function oxidases. 
Establishing that a correlation exists between antipyrine half life and petrol exposure would add weight to the hypothesis that petrol is the inductive agent. Attempts, however, to find an acceptable index of exposure to petrol proved unsuccessful. In previous studies phenol output in the urine has been used. ${ }^{21-24}$ This method is based on the metabolism of benzene in the liver, producing phenol that is then conjugated and excreted. The major problem with this method is that the benzene content of petrol depends on the source of the crude oil from which the petrol is refined. In the study by Pandya et al $^{22}$ the benzene content was quoted as $10-17 \%$ of petrol, but Sherwood ${ }^{24}$ quoted $5 \%$. In Adelaide the benzene content of petrol is about $3 \%$; hence the sensitivity of the method would be substantially reduced. Although greater variability in phenol excretion was found in our sample of petrol station attendants, the amount excreted did not differ from that in the controls.

Since tetraethyl lead is added to petrol as an "anti-knock" agent, increases in body lead concentrations might be expected in petrol station attendants. Lob ${ }^{25}$ found blood lead concentrations ranging from 0.80 to $2.95 \mu \mathrm{mol} / 1$ (mean $1.30 \mu \mathrm{mol} / \mathrm{l}$ ) in office workers and values of 1.11 to $2.85 \mu \mathrm{mol} / \mathrm{l}$ (mean $1.84 \mu \mathrm{mol} / \mathrm{l}$ ) in garage attendants. Moore $e t$ $a l^{26}$ found that blood lead in petrol vendors was $1.58 \pm 0.08$ (SE) $\mu \mathrm{mol} / \mathrm{l}$, and this was greater than in a control population of public servants and university personnel, which was $0.69 \pm 0.03 \mu \mathrm{mol} / \mathrm{l}$. In the petrol-exposed subjects of the present study the mean value was less than that found for office workers in Lob's study, and the higher values were less than the upper $95 \%$ confidence limits expected in non-exposed workers. ${ }^{15}$ Thus blood lead concentrations did not differentiate the petrol station attendants in this study from the normal non-exposed population, nor did either ALAD activity in blood or urinary lead excretion, which were also within the normal range.

Although the metabolism of antipyrine has been found to be primarily under genetic control, ${ }^{27}$ other factors, such as age, sex, ${ }^{28}$ and smoking, ${ }^{29}$ have been shown to alter its rate of metabolism. With this in mind, some personal and social measures were examined in the 19 petrol station attendants in an attempt to explain the difference in antipyrine metabolism, but no relation was found between antipyrine half life and age, work duration, smoking, or alcohol and caffeine intake. Furthermore, the distributions found for both smoking and caffeine intake were very close to those found in 307 healthy male North Americans. ${ }^{28}$ This suggests that the drinking and smoking habits of the petrol-exposed group are not radically different from the general population and that the altered metabolism of antipyrine cannot be attributed to differences in social habits.

Since antipyrine metabolism shows a two to threefold variation in the general population, small changes in the activity of the enzymes that metabolise this compound are difficult to show when comparing two heterogeneous subgroups. This was illustrated in a study of antipyrine elimination in anaesthetists, ${ }^{5}$ where the inductive effect of trace levels of inhalational anaesthetics could be verified statistically only when intra-individual comparisons were made, but not when intergroup comparisons were made between anaesthetists and a control group. This might suggest that the inductive effect of exposure to petroleum is more substantial than that of exposure to traces of anaesthetic gases. The relation, however, between degree of shortening of antipyrine half life and the potency of the inducing agent is difficult to interpret because of the pronounced inter-individual variances. In the present study the decrease in antipyrine half life was $17 \%$, and this is smaller than the $47 \%$ decrease seen in workers exposed to insecticides. ${ }^{3}$ In interpreting these changes, however, it must be borne in mind that in the latter study the mean half life of the control population was $13 \mathrm{hr}$ compared with the $11.3 \mathrm{hr}$ in the present study.

In conclusion the results indicate that petrol vapour is a moderately potent inducer of microsomal mixed function oxidases in rats, and that occupational exposure to petroleum may result in enhanced microsomal drug metabolism in man.

We thank Dr R G Edwards and the staff of the division of clinical chemistry, Institute of Medical and Veterinary Science, Adelaide, for their help with the estimation of lead concentrations in blood and urine. Mrs L L Kingston provided expert secretarial help.

\section{References}

1 Conney AH. Pharmacological implications of microsomal enzyme induction. Pharmacol Rev 1967;19:317-66.

2 Remmer H. Induction of the drug metabolizing enzyme system of the liver. Eur J Clin Pharmacol 1972;5:116-36.

${ }^{3}$ Kolmodin B, Azarnoff DL, Sjoqvist F. Effect of environmental factors on drug metabolism: decreased plasma half-life of antipyrine in workers exposed to chlorinated hydrocarbon insecticides. Clin Pharmacol Ther 1969;10: 638-42.

${ }^{4}$ Krampl V, Kontsekova M. Effect of polychlorinated biphenyls on the elimination rate of antipyrine from plasma of rats and man. Bull Environ Contam Toxicol 1978;20:191-8.

${ }^{5}$ Harman AW, Russell WJ, Frewin DB, Priestly BG. Altered drug metabolism in anaesthetists exposed to volatile anaesthetic agents. Anaesthesia and Intensive Care 1978;6:210-14. 
${ }^{6}$ Stevenson IH. Factors affecting antipyrine elimination. Br J Clin Pharmacol 1977;4:261-5.

${ }^{7}$ Harman AW, Penhall RK, Priestly BG, Frewin DB, Phillips PJ, Clarkson AR. Salivary antipyrine kinetics in hepatic and renal disease and in patients on anticonvulsant therapy. Aust NZ J Med 1977;7:385-90.

${ }^{8}$ Schmidt EG. Urinary phenols. IV The simultaneous determination of phenol and p-cresol in urine. J Biol Chem 1949;179:211-5.

${ }^{9}$ Chakrabarti SK, Brodeur J, Tardiff R. Fluorometric determination of delta-aminolaevulinate dehydratase activity in human erythrocytes as an index to lead exposure. Clin Chem 1975;21:1783-7.

${ }^{10}$ Fernandez FJ. Micromethod for lead determination in whole blood by atomic absorption, with use of the graphite furnace. Clin Chem 1975;21:558-61.

"Schenkman JB, Remmer H, Estabrook RW. Spectral studies of drug interaction with hepatic microsomal cytochrome. Mol Pharmacol 1967;3:113-23.

12 Nebert DW, Gelboin HV. Substrate-inducible microsomal aryl hydroxylase in mammalian cell culture. $J$ Biol Chem 1968;243:6242-9.

${ }^{13}$ Bakke OM, Bending J, Aarbakke J, Davies DS. ${ }^{14} \mathrm{C}-$ antipyrine as a model compound in the study of drug oxidation and enzyme induction in individual surviving rats. Acta Pharmacol Toxicol 1974;35:91-7.

14 Colquhoun D. Lectures on biostatistics. Oxford: Clarendon Press, 1971.

15 Green VA, Wise GW, Callenbach J. Lead poisoning. Clin Toxicol 1976;9:33-51.

18 Meredith PA, Moore MR, Campbell BC, Thompson GE, Goldberg A. Delta-aminolaevulinic acid metabolism in normal and lead-exposed humans. Toxicology 1978;9: 1-8.

${ }^{17}$ Lauwerys RR, Buchet J-P, Roels HA. Comparative study of the effects of inorganic lead and cadmium on the blood delta-aminolevulinate dehydratase in man. $\mathrm{Br} J$
Ind Med 1973;30:359-64.

${ }^{18}$ Payne JF, Penrose WR. Induction of aryl hydrocarbon (benzo(a)pyrene hydroxylase) in fish by petroleum. Bull Environ Contam Toxicol 1975;14:112-6.

19 Carlson GP. Induction of cytochrome P450 by halogenated benzenes. Biochem Pharmacol 1978;27:361-3.

${ }^{20}$ Raitcheva V, Zlatarev $O$. Chronic effect of petroleum derivatives on enzyme constellations. Industrial Medicine 1970;39:34-5.

${ }^{21}$ Docteur HJ, Zielhuis RL. Phenol excretion as a measure of benzene exposure. Ann Occup Hyg 1967;10:317-26.

${ }^{22}$ Pandya KP, Rao GS, Dhasmana A, Zaidi SH. Occupational exposure of petrol pump workers. Ann Occup Hyg 1975;18:363-4.

${ }^{23}$ Parkinson GS. Benzene in motor gasoline-an investigation into possible health hazards in and around filling stations and in normal transport operations. Ann Occup Hyg 1971;14:145-53.

${ }^{24}$ Sherwood RJ. Evaluation of exposure to benzene vapour during the loading of petrol. Br J Ind Med 1972;29:65-9.

${ }^{25}$ Lob M. Apropos of leaded gasoline. II Comparative study of lead in blood, urinary lead and urinary porphyrins in various groups of the people of Lausanne (office workers, garage mechanics, policemen). Zeitschrift fur Praeventivmedizin $1965 ; 10: 172-6$

${ }^{26}$ Moore PJ, Pridmore SA, Gill GF. Total blood lead levels in petrol vendors. Med $J$ Aust 1976;1:438-40.

${ }^{27}$ Vesell ES, Page JG. Genetic control of drug levels in man: antipyrine. Science $1968 ; 161: 72-3$.

${ }^{28}$ Vestal RE, Norris AH, Tobin JD, Cohen BH, Shock NW, Andres R. Antipyrine metabolism in man: influence of age, alcohol, caffeine and smoking. Clin Pharmacol Ther 1975;18:425-32.

${ }^{29}$ Hart P, Farrell GC, Cooksley WGE, Powell LW. Enhanced drug metabolism in cigarette smokers. Br Med J 1976;ii: 147-9. 